\title{
Factors Inhibiting Indonesia-Timor Leste Border Delimi- tation in Manusasi Village (2014-2018)
}

\author{
Faktor Penghambat Delimitasi Batas Darat Indone- \\ sia-Timor Leste di Desa Manusasi (2014-2018)
}

\author{
Novitasari Annisa Putri \& Sukmawani Bela Pertiwi \\ Bina Nusantara University
}

\begin{abstract}
ABSTRAK
Penelitian ini bertujuan untuk membahas faktor penghambat delimitasi batas darat yang dilakukan oleh pemerintah Indonesia dan Timor Leste pada unresolved segment di Desa Manusasi periode 2014-2018. Penelitian ini menggunakan issuelevel approach dari kajian sengketa wilayah yang menyatakan bahwa kombinasi faktor kewilayahan dan visibilitas domestik merupakan faktor yang berpengaruh terhadap dinamika sengketa wilayah. Dalam hal ini, dinamika sengketa yang masih berlangsung namun relatif stabil disebabkan karena kombinasi kewilayahan yang memiliki nilai, baik tampak maupun tidak tampak, namun visibilitas di level nasional kurang. Argumennya, wilayah yang memiliki nilai tertentu akan sulit diselesaikan sehingga memerlukan waktu lama. Namun kurangnya visibilitas sengketa diantara masyarakat di level nasional membuat tensi tetap stabil dikarenakan absennya tekanan dari masyarakat kepada pemerintah untuk menyelesaikan sengketa ini. Penelitian ini menemukan bahwa kombinasi kedua faktor ini juga berpengaruh dalam kasus delimitasi batas darat Indonesia-Timor Leste di Manusasi hingga 2018.
\end{abstract}

Kata Kunci: Delimitasi Batas Darat, Indonesia-Timor Leste, Desa Manusasi (Bijael Sunan-Oben)

This research aims to discuss factors inhibiting land border delimitation between Indonesia and Timor Leste on the unresolved segment in Manusasi Village between 2014 and 2018. This research uses issue-level approach from the study of territorial dispute which stated that the combination of territoriality and domestic visibility are among factors contributing to the dynamics of territorial disputes. In this case, the dynamics of the dispute which was still ongoing yet relatively stable is the result of the combination of its territoriality which is salient for its tangible or intangible value. However, the lack of visibility among audience at the national level keep the tension of the dispute stable because of the lack of pressure from the society to the government to solve this dispute. This research found that the combination of these two factors also contributes to the case of land border delimitation between Indonesia and Timor Leste in Manusasi until 2018.

Keywords: Land Border Delimitation, Indonesia-Timor Leste, Manusasi Village (Bijael Sunan-Oben) 
Batas darat antara Indonesia dan Timor Leste memiliki tiga titik wilayah bersengketa yang masih belum menemukan kesepakatan hingga tahun 2018 kemarin. Ketiga titik wilayah sengketa yang tersisa memiliki masalahnya masing-masing. Masalah perbatasan di Subina-Oben yaitu perbedaan penafsiran penarikan batas antara hasil kesepakatan kedua pemerintah dengan masyarakat Indonesia. Wilayah sengketa Noel Besi-Citrana terjadi karena adanya pergeseran batas alam yang menjadi patokan batas kedua negara. Sejak jaman penjajahan Portugis, garis batas di wilayah tersebut mengacu pada aliran sungai Noel Besi yang mengalir ke kiri di luar wilayah bersengketa, namun akibat perubahan alam dan iklim menyebabkan pergeseran aliran sungai di wilayah tersebut, sehingga menimbulkan sengketa wilayah dalam mengklaim garis batas (Sianipar 2017). Wilayah Desa Manusasi memiliki permasalahan yang lebih kompleks. Desa Manusasi merupakan wilayah kosong yang tidak didiami dan tidak digunakan oleh masyarakat. Wilayah tersebut terletak di Kecamatan Miomaffa Barat dan merupakan batas antara Kabupaten TTU, Indonesia dengan Distrik Oecussi, Timor Leste. Meskipun demikian, Desa Manusasi dikelilingi oleh masyarakat adat dari kedua negara yang memiliki hubungan kekeluargaan, baik karena adanya pernikahan lintas negara maupun karena berasal dari keturunan yang sama. Hal tersebut membuat negosiasi lebih rumit karena dalam menentukan garis batas, dinamika yang ada tidak hanya terjadi di level pemerintah tetapi juga di level masyarakat, sehingga pemerintah perlu melihat kondisi masyarakat tersebut (Sianipar 2017).

Dalam penentuan garis batas di Desa Manusasi, masyarakat adat kedua negara memiliki keinginan berbeda. Masyarakat sekitar yang ada di bagian Indonesia menginginkan wilayah di Desa Manusasi masuk Indonesia dengan melakukan pengukuran menggunakan pilar yang ditanam pertama kali pada tahun 1966 oleh pemerintah Indonesia. Di sisi lain, masyarakat sekitar yang ada di bagian Timor Leste menginginkan penggunaan pilar kedua yang disepakati Belanda dan Portugis pada tahun 1915 agar wilayah tersebut menjadi bagian dari Timor Leste (Sianipar 2017). Dengan kondisi tersebut, kedua pemerintah memiliki posisi yang berbeda dalam menyelesaikan masalah di Desa Manusasi. Posisi pemerintah Indonesia berpendapat bahwa keberadaan masyarakat adat di wilayah tersebut perlu dihormati, oleh karena itu keinginan masyarakat adat perlu menjadi pertimbangan. Sedangkan posisi Timor Leste menyatakan, terlepas dari kondisi masyarakat yang ada di wilayah tersebut, garis paling dekat dengan yang tertera dalam traktat 1904 merupakan garis batas RIRDTL, karena traktat 1904 disetujui kedua pemerintah sebagai acuan penyelesaian batas wilayah (Badan Infomasi Geospasial 2016). Kompleksitas masalah sengketa wilayah di Desa Manusasi ini menjadikan wilayah tersebut lebih menarik serta penting untuk dibahas. Terlebih sengketa ini telah berlangsung selama 16 tahun sehingga penyelesaian sengketa tidak hanya akan membantu terciptanya hubungan baik dan keamanan kedua negara tetapi juga kejelasan bagi masyarakat setempat (BNPP 2018).

Dengan latar belakang tersebut, tulisan ini bertujuan untuk mendiskusikan faktorfaktor yang menghambat delimitasi batas darat antara Indonesia dan Timor Leste di Desa Manusasi. Sejauh ini sebagian besar literatur yang ada lebih melihat upaya yang dilakukan dalam menjaga keamanan perbatasan kedua negara (Gumilar 2017) dan upaya penyelesaian sengketa perbatasan Indonesia dan Timor Leste secara umum (Raharjo 2016; Sianipar 2017; Qinvi, Sutisna, dan Widodo 2018). Selain itu, literatur yang ada juga mengedepankan aspek teknis dan hukum dalam penyelesaian sengketa (Bangun 2017; Gumilar 2017; Mangku 2017; Quefi et.al 2019). Kecenderungan ini pun juga terjadi pada literatur-literatur yang mengkaji sengketa wilayah pada umumnya. 
Oleh karena itu, tulisan ini bertujuan untuk mengkaji sengketa wilayah Desa Manusasi secara khusus dengan menggunakan perspektif Hubungan Internasional melalui issue-level approach. Argumennya, sengketa wilayah tidak hanya permasalahan legal dan teknis, tetapi juga politis. Issue-level approach dalam hal ini bermanfaat untuk melihat dinamika politis dalam sengketa wilayah yang disebabkan oleh kombinasi faktor kewilayahan dan visibilitas sengketa diantara masyarakat di level nasional.

Untuk dapat melihat pengaruh kedua faktor tersebut, tulisan ini didasarkan pada penelitian dengan metode campuran. Data kewilayahan dan kronologi sengketa didapatkan dari data primer dari pemerintah terkait dan sekunder dari literatur. Sementara itu, data visibilitas di level nasional, karena berkaitan dengan opini publik yang akan dijelaskan lebih lanjut pada bagian selanjutnya, didapatkan melalui media tracking di media nasional rangking atas di kedua negara. Media di Indonesia yang dipilih meliputi Detik.com, Kompas.com, dan Liputan 6. Ketiga media tersebut memiliki jumlah pembaca terbanyak dibandingkan dengan media lainnya (Morgan 2018). Sedangkan media di Timor Leste yang digunakan adalah Suara Timor Lorosae dan Dilli Weekly. Keduanya merupakan media yang diakui kredibilitasnya oleh Timor Leste (Kemlu RI 2018). Untuk memfokuskan analisa, pengamatan dibatasi pada rentang waktu 2014-2018 dimana dinamika pada periode tersebut relatif seragam, yaitu sengketa masih berlangsung namun tensinya tetap stabil. Dalam menjabarkan penjelasannya, tulisan ini akan dibagi menjadi beberapa bagian. Bagian pertama akan memberikan penjelasan tentang kerangka analisa yang digunakan yaitu issuelevel approach. Bagian kedua kemudian akan memberikan konteks sengketa wilayah di Manusasi sebelum akhirnya bagian berikutnya mendiskusikan faktor penghambat penyelesaian sengketa dengan menggunakan kerangka analisa yang dipilih.

\section{Kerangka Analisis Issue Level Approach}

Pada dasarnya, dalam mengkaji sengketa wilayah dalam perspektif Hubungan Internasional, terdapat tiga pendekatan yaitu, International-Level-Approach; Regional-Level-Approach; dan Issue-Level-Approach (Pertiwi 2014). Pendekatan pertama yaitu International-Level-Approach merupakan pendekatan yang paling mendominasi. Dalam menjelaskan dinamika sengketa wilayah, pendekatan pada level ini dapat dilihat dari tiga perspektif besar Hubungan Internasional, yaitu realisme, konstruktivisme, dan liberalisme. Namun, dalam menganalisis dinamika yang ada di level lokal seperti Desa Manusasi, pendekatan ini dirasa kurang tepat karena membahas masalah terlalu luas yaitu dalam skala internasional, yang biasanya melihat peran sistem internasional atau struktur internasional dan peran major power dalam suatu isu tertentu.

Pendekatan kedua adalah Regional-Level-Approach. Pada level ini, dinamika sengketa wilayah di suatu kawasan erat kaitannya dengan peran institusi regional yang ada (Pertiwi 2014). Institusi regional dibentuk dengan berbagai tujuan, salah satunya adalah menjembatani penyelesaian konflik dan perdamaian yang terjadi di kawasan. Oleh karenanya, pendekatan ini melihat adanya dampak positif dari keberadaan institusi regional terhadap sengketa yang muncul dalam kawasan tersebut. Meskipun demikian, pendekatan ini juga kurang dapat diaplikasikan pada kasus Desa Manusasi karena pada upaya penyelesaian sengketa di Desa Manusasi, baik pihak Indonesia maupun Timor Leste tidak membawa masalah ini hingga level ASEAN. 
Pendekatan ketiga yaitu Issue-Level-Approach. Pendekatan pada level ini dapat dikatakan paling relevan, karena melihat sengketa dari dinamika yang ada di wilayah itu sendiri (Pertiwi 2014). Pada dasarnya, issue-level-approach melihat dinamika sengketa wilayah dari sisi kewilayahannya (territoriality). Pernyataan tersebut disampaikan oleh peneliti terdahulu yaitu Paul R. Hensel dan Sara Mclaughlin (Hensel and Mclaughlin 2005) dan Daniel J. Dzurek (Dzurek 2005) yang menyatakan bahwa dinamika sengketa wilayah dipengaruhi nilai yang dimiliki wilayah yang bersengketa, yaitu salient atau tidaknya wilayah tersebut. Indikator untuk menjelaskan salient atau tidaknya sebuah wilayah yaitu dengan memperhatikan nilai tampak (tangible) dan nilai tidak tampak (intangible) wilayah tersebut. Terdapat tiga nilai tampak (tangible) yang perlu diperhatikan. Pertama, sumber daya alam di wilayah tersebut, yakni potensi alam yang dimiliki suatu wilayah yang dapat menjadi sumber perekonomian bagi negara yang memilikinya, sehingga keberadaannya akan lebih mudah menimbulkan konflik sengketa. Kedua, potensi alam yang berpengaruh terhadap power (kekuatan) dan stabilitas negara. Wilayah yang memiliki lokasi strategis lebih cenderung mudah menimbulkan sengketa wilayah. Ketiga, keberadaan penduduk lokal di wilayah tersebut. Untuk nilai tidak tampak (intangible), indikatornya adalah kondisi yang tidak terlihat wujudnya, memiliki lebih banyak hal simbolis yang menjadi ciri khas sebuah wilayah, serta menggambarkan keterkaitan emosional antar penduduk setempat. Sengketa yang melibatkan nilai tidak tampak (intangible) cenderung membuat tensi sebuah konflik tinggi, karena tidak dapat dibagi (indivisible) (Hensel and Mclaughlin 2005; Dzurek 2005).

Melalui tulisan yang berjudul The Rise of Territorial Disputes and the Stability of Southeast Asia, Sukmawani Bela Pertiwi mengembangkan pemikiran tersebut, bahwa nilai sengketa wilayah tidak hanya melihat kewilayahannya (territoriality) saja, namun juga dipengaruhi tingkat visibilitas isu tersebut di masyarakat maupun pemangku kebijakan pada tingkat nasional (Pertiwi 2014). Sengketa wilayah berbeda dengan sengketa lainnya karena rawan memunculkan rasa nasionalis masyarakat. Hal tersebut dapat mendorong masyarakat untuk melakukan tekanan terhadap pemerintah agar segera menyelesaikan masalah yang ada. Oleh karena itu, tingkat visibilitas menjadi satu hal yang juga penting dalam melihat dinamika sengketa perbatasan. Suatu sengketa dikatakan terlihat pada tingkat nasional (visible) jika sengketa diberitakan paling tidak oleh dua media massa ternama pada level nasional dari masing-masing negara saat sengketa berlangsung. Sedangkan sengketa dikatakan tidak terlihat pada tingkat nasional (not visible) jika sengketa bahkan tidak dibahas dalam media massa nasional ternama karena adanya peralihan isu, adanya masalah yang lebih membutuhkan perhatian dari pemerintah, atau lokasi wilayah sengketa yang berada jauh dari pusat pemerintahan sehingga informasi tidak menjangkau ke pusat pemerintahan atau tidak mendapat perhatian sebagian besar masyarat di level nasional. Pada kondisi ini, tidak ada tekanan dari opini publik untuk pemerintah segera mengambil tindakan untuk menyelesaikan sengketa. Indikator nilai sebuah wilayah dan tingkat visibilitas sengketa wilayah dapat dilihat pada tabel di bawah ini: 
Tabel 1.1 Tabel Indikator Kewilayahan dan Visibilitas

\begin{tabular}{|c|c|c|}
\hline Variabel & Komponen & Indikator \\
\hline Kewilayahan & $\begin{array}{ll}\text { - } & \text { Salient } \\
\text { - } & \text { Tidak Salient }\end{array}$ & 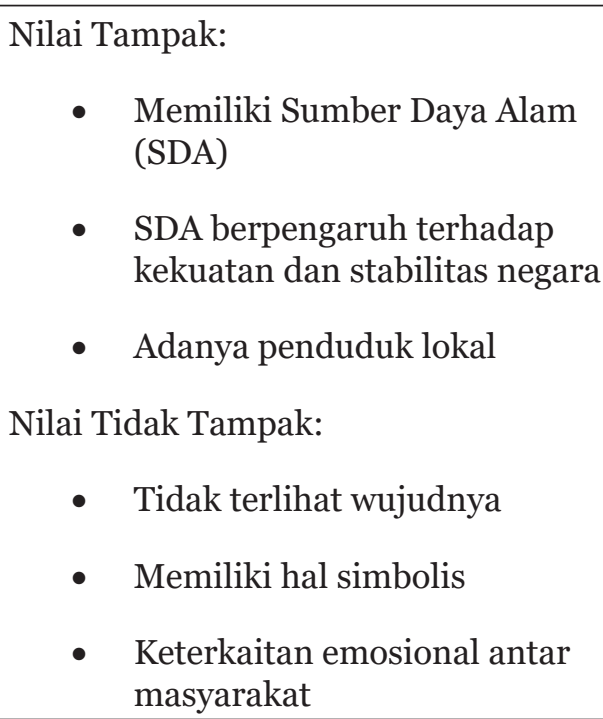 \\
\hline Visibilitas & $\begin{array}{ll}\text { - } & \text { Terlihat } \\
\text { - } & \text { Tidak Terlihat } \\
\end{array}$ & $\begin{array}{l}\text { Minimal diberitakan dua media tiap } \\
\text { negara saat sengketa berlangsung }\end{array}$ \\
\hline
\end{tabular}

(Sumber: Pertiwi, 2014)

Berdasarkan pengamatan di Asia Tenggara, kombinasi kondisi kewilayahan (territoriality) dan visibilitas yang berbeda dalam sengketa wilayah, akan menghasilkan dinamika yang berbeda juga, yaitu tidak stabil (unstable), relatif stabil (relatively stable), penyelesaian secara damai (peacefully resolved), atau dormant (Pertiwi 2014). Sengketa wilayah disebut tidak stabil (unstable) ketika tekanan tehadap pemerintah untuk mempertahankan suatu wilayah yang bersengketa meningkat serta merujuk pada konflik militer terbuka. Pada kondisi relatif stabil (relatively stable), sengketa wilayah masih berlangsung dan pemerintah kedua negara juga masih melakukan proses negosiasi, namun sengketa wilayah tersebut tidak merujuk pada konflik militer terbuka. Selain itu jangka waktu penyelesaiannya juga tidak ditentukan. Sengketa dikatakan terselesaikan secara damai (peacefully resolved) yaitu ketika berada pada kondisi dimana sengketa wilayah sudah benar-benar terselesaikan baik melalui kesepakatan bilateral maupun pihak ketiga. Terakhir yaitu dormant, pada kondisi ini terdapat sengketa wilayah namun dalam kurun waktu lima tahun ke belakang, tidak ada perundingan untuk menyelesaikan sengketa yang ada maupun indikasi untuk konflik militer terbuka.

Pertiwi menjelaskan empat kombinasi atau tipologi dari hubungan nilai sebuah wilayah dan visibilitas sengketa terhadap dinamika sengketa wilayah. Pertama, suatu sengketa yang melibatkan wilayah bernilai salient dan terlihat oleh masyarakat nasional, maka sengketa wilayahnya akan cenderung tidak stabil. Hal ini dikarenakan, wilayah dengan nilai penting di dalamnya (salient) akan cenderung dipertahankan oleh pemerintah, terlebih saat sengketa ini terlihat di masyarakat, yang mana akan mendorong 
masyarakat untuk melakukan sebuah gerakan seperti demonstrasi terkait masalah sengketa yang ada. Pada tingkatan pemerintah, akan ada bagian dari pemerintahan yang mendorong pemimpin negara untuk mengambil sikap atas masalah yang ada, bahkan membawa pada konflik militer terbuka.

Kedua, pada wilayah yang bernilai salient namun tidak terlihat oleh masyarakat di level nasional, maka sengketa wilayahnya akan cenderung relatif stabil. Hal tersebut dikarenakan, meskipun wilayahnya penting bagi pemerintah, namun karena isu ini tidak terlihat masyarakat nasional baik karena adanya masalah lain yang lebih penting maupun karena lokasinya yang jauh dari pemerintah pusat, sehingga dalam upaya penyelesaiannya pemerintah tidak menjadikannya sebagai masalah utama yang harus segera dilakukan.

Ketiga, jika wilayah sengketa tidak salient tetapi terlihat oleh masyarakat pada level nasional, maka sengketa wilayah akan cenderung dapat diselesaikan secara damai. Pada kondisi ini, wilayah yang tidak bernilai penting (not salient) akan tetap diupayakan penyelesaian sengketanya oleh pemerintah. Namun, dengan kondisi yang terlihat di masyarakat (visible), akan semakin mendorong pemerintah untuk segera menyelesaikannya karena pada posisi ini akan lebih mudah menyelesaikannya.

Kombinasi terakhir yaitu, apabila wilayah sengketa tidak salient dan tidak terlihat oleh masyarakat serta pemangku kebijakan secara nasional, maka sengketanya akan cenderung dormant. Pada kondisi ini, negara berkembang dengan banyak hal lain yang perlu diselesaikan akan membuat sengketa wilayah cenderung dikesampingkan. Pemerintah akan memprioritaskan masalah lain sehingga menyebabkan tidak ada aktivitas seperti perundingan maupun kegiatan sebagai bentuk penyelesaian dalam kurun waktu lima tahun (dormant). Untuk melihat dinamika mana yang tampak dalam sengketa wilayah Indonesia-Timor Leste di Manusasi, bagian berikut akan memberikan konteks kronologi sengketa wilayah kedua negara di wilayah tersebut.

Tabel 1.2 Kewilayahan, Visibilitas, Dinamika Sengketa

\begin{tabular}{|lll|}
\hline \multicolumn{1}{|c|}{ Kewilayahan } & \multicolumn{1}{c|}{ Visibilitas } & Dinamika Sengketa \\
\hline Salient & Terlihat & Tidak Stabil \\
\hline Salient & Tidak Terlihat & Relatif Stabil \\
\hline Tidak Salient & Terlihat & Terselesaikan damai \\
& & \\
\hline Tidak Salient & Tidak Terlihat & Dormant \\
& & \\
\hline
\end{tabular}

(Sumber: Pertiwi, 2014) 


\section{Konteks Dinamika Sengketa Wilayah Perbatasan Indonesia-Timor Leste}

Sengketa kedua negara bermula sejak Perserikatan Bangsa-Bangsa (PBB) melalui United Nations Mission in East Timor (UNAMET) memfasilitasi masyarakat Timor Timur untuk melakukan referendum pada tahun 1999 guna menyuarakan keinginannya untuk keluar dari Indonesia dan menjadi negara yang berdaulat (Qinvi, Sutisna, \& Widodo 2018). Setelah referendum terlaksana, masyarakat pro kemerdekaan Timor mempersiapkan kemerdekaannya. Pasca Timor Timur memutuskan untuk melepaskan diri dari Indonesia, kedua pemerintah mulai melakukan perundingan terkait penegasan batas wilayah kedua negara. Pertemuan dan perundingan pertama tim gabungan antara pemerintah Indonesia dan UNTAET berlangsung pada tahun 2001. Pada pertemuan tersebut juga dibentuk Joint Border Committee (JBC) untuk membahas penegasan batas wilayah kedua negara (Sianipar 2017).

Pada 20 Mei 2002 Timor Timur mendeklarasikan kemerdekaannya dan menggunakan nama Republik Demokratik Timor Leste (RDTL). Presiden pertama Timor Leste yang terpilih, Xanana Gusmao, menginginkan adanya hubungan baru dengan Indonesia dan adanya rekonsiliasi antara kedua negara (Liputan 6 2009). Masa-masa ini merupakan proses transisi Timor Leste menjadi negara berdaulat dengan mengurus masalah domestiknya sendiri. Setelah Timor Leste merdeka, seluruh perundingan penegasan garis batas dilaksanakan oleh pemerintah Indonesia dan Timor Leste. Di tahun yang sama, pertemuan antar Menteri Luar Negeri kedua negara dalam Joint Ministerial Commission (JMC) juga dilaksanakan untuk pertama kalinya guna membahas dan menyelesaikan residu terkait garis batas di wilayah perbatasan. Pada pertemuan tersebut salah satu keputusan yang disepakati adalah menugaskan tim Technical SubCommittee on Border Demarcation and Regulation (TSC-BDR) untuk melakukan survey deliniasi dan demarkasi (Handoyo 2011).

Proses perundingan yang dilakukan oleh kedua belah pihak memerlukan sebuah kesepakatan untuk dijadikan dasar dalam menentukan sebuah kebijakan. Pemerintah Indonesia dan Timor Leste menganut asas Utti Prosidetis Jurris, yang mana hal tersebut mengacu pada batas negara era penjajahan Belanda dan Portugis (Qinvi, Sutisna, \& Widodo 2018). Upaya perundingan antara pemerintah Indonesia-Timor Leste dalam menyelesaikan sengketa perbatasan yang masih tersisa juga menyepakati beberapa perjanjian yang sudah lebih dulu disepakati. Hal tersebut dimaksudkan untuk menjadi tolak ukur dalam proses perundingan dan survey bersama sebagai bentuk upaya penyelesaian batas darat kedua negara. Dalam hal ini, keduanya menyepakati Traktat tahun 1904 antara pemerintah Belanda dengan pemerintah Portugis, serta Permanent Court Award (PCA) tahun 1914 sebagai dasar hukum dalam proses perundingan (Sianipar 2017).

Dengan mengacu pada perjanjian tersebut, tim TSC-BDR melakukan pengukuran di kawasan perbatasan guna memverifikasi keadaan garis batas yang tertera dalam perjanjian dengan kondisi yang ada di lapangan. Setelah proses survei bersama dilaksanakan, tahun 2004 para tim TSC-BDR mengeluarkan sebuah laporan yang disebut Interim Report. Laporan tersebut berisi hasil pengukuran dan penetapan garis batas di 907 titik perbatasan Indonesia dengan Timor Leste. Pada tahun 2005 pemerintah Indonesia-Timor Leste berhasil mencapai Provisional Agreement between the Government of the Republic of Indonesia and the Government of the Democratic Republic of Timor Leste on the Land Boundary setelah hasil interim report disahkan pada 8 Juni 2005 oleh tim JBC (Mangku 2017). Provisional 
Agreement tersebut merupakan perjanjian sementara pemerintah RI-RDTL yang telah berhasil menyelesaikan hampir seluruh garis batas kedua negara dan menyisakan tiga unresolved dan satu unserveyed segments. Letak unresolved segment berada di Noel Besi-Citrana, Desa Manusasi dan Dilumil-Memo, sedangkan unsurveyed segment berada di Subina-Oben (Qinvi, Sutisna, \& Widodo 2018).

Proses perundingan disepakati untuk terus dilakukan oleh kedua pemerintah guna menyelesaikan sengketa wilayah perbatasan yang masih tersisa. Namun, pada tahun 2006 Timor Leste memiliki masalah domestikyang cukup berat. Krisis politik keamanan dirasakan oleh Timor Leste, selain itu harga-harga kebutuhan menjadi sangat mahal dikarenakan penggunaan dolar Amerika sebagai mata uangnya. Tahun selanjutnya Timor Leste juga masih menyelesaikan urusan domestiknya. Hal tersebut dilakukan karena pada tahun 2007, Timor Leste melakukan pemilihan presiden. Keberhasilan dari pemilu yang berlangsung menjadi sebuah pembuktian bahwa keputusan Timor Leste untuk merdeka merupakan langkah yang tepat, sehingga politisi di Timor Leste berfokus pada pemilu yang berlangsung. Hasil pemilihan presiden tersebut dimenangkan oleh Ramos Horta, yang sebelumnya merupakan Perdana Menteri di pemerintahan Xanana Gusmao (Liputan 6 2009). Dengan kondisi tidak kondusif yang terjadi di Timor Leste, perundingan terkait sengketa wilayah perbatasan yang rutin dilakukan oleh kedua pemerintah, tidak terlaksana selama dua tahun.

Setelah kondisi politik domestik Timor Leste mulai lebih stabil, kedua pemerintah kembali melaksanakan perundingan. Namun, di tahun 2012 masyarakat kedua negara terlibat dalam konflik komunal. Kedua kelompok masyarakat yang ada di perbatasan RI-RDTL saling lempar batu dan saling serang menggunakan senjata tajam. Hal tersebut dipicu adanya pelanggaran batas wilayah yang dilakukan pemerintah RDTL, dengan membangun kantor Bea Cukai hingga masuk ke wilayah Indonesia di Desa Haumaeni Ana Kecamatan Bikomi Nilulat Kabupaten TTU. Perbuatan yang dilakukan pemerintah Timor Leste tersebut, menimbulkan kemarahan warga Indonesia di wilayah Desa Haumaeni Ana, sehingga terjadi lah bentrok masyarakat Indonesia dengan masyarakat Timor Leste yaitu warga Pasabe, Distrik Oekusi. Beruntung pihak keamanan kedua negara berhasil meredam emosi kedua kubu, sehingga bentrok yang berlangsung tidak menjadi hal berkepanjangan yang bisa menimbulkan kondisi tidak kondusif bagi wilayah pebatasan (Bere, S.M. 2012).

Disamping dinamika yang terjadi selama masa upaya penegasan batas wilayah antara kedua negara, perundingan tetap dilaksanakan dengan cara damai oleh kedua pemerintah, hingga pada tahun 2013, salah satu titik unresolved segment yaitu Dilumil-Memo, berhasil mencapai kesepakatan setelah mendapat persetujuan Special JBC terkait hasil pertemuan Special Working Group (SWG) yang merekomendasikan penyelesaian sengketa wilayah perbatasan menggunakan median line pada kasus tersebut. Hingga 2018 sengketa perbatasan RI-RDTL masih menyisakan dua unresolved segment dan satu unsurveyed segment yang perlu diselesaikan Indonesia (Qinvi, Sutisna, \& Widodo 2018).

Pada tahun yang sama setelah Dilumil - Memo berhasil terselesaikan, kembali terjadi bentrok antara masyarakat Dusun Sunsea, Desa Nelu, Kecamatan Naibenu, Kabupaten TTU, Indonesia dan warga Leolbatan, Desa Kosta, Kecamatan Kota, Distrik Oecussi, Timor Leste. Bentrok keduanya berawal dari pelanggaran yang dilakukan pemerintah Timor Leste karena membangun jalanan hingga masuk ke wilayah Indonesia dan tempat pemakaman masyarakat Desa Nelu. Warga Sunsea tidak menerima hal tersebut 
dengan melakukan penutupan jalan. Hal tersebut direspon warga Leolbatan dengan membawa senjata tajam, hingga akhirnya bentrok antar dua kelompok warga negara tidak terhindarkan dan berlangsung selama tiga hari (Seo 2013). Tidak berselang lama kedua pemerintah negara beradu klaim terkait kerusakan tapal batas yang berada di antara kedua wilayah Indonesia dan Timor Leste tersebut. Pemerintah Indonesia menyatakan bahwa masyarakat Desa Kosta yang telah merusak tapal batas tersebut. Sebaliknya, pemerintah Timor Leste juga mengatakan bahwa masyarakat Desa Nelu yang merusaknya (Seo 2013).

Terlepas dari bentrok yang terjadi antara kedua warga negara, dengan tercapainya kesepakatan terkait sengketa RI-RDTL di Dilumil-Memo, pemerintah kedua negara semakin mempererat hubungan bilateral dan semakin berkomitmen untuk menyelesaikan sengketa wilayah perbatasan yang masih tersisa. Upaya penyelesaian dua titik wilayah unresolved segment guna menjaga stabilitas dan keamanan negara, pemerintah terus melakukan perundingan untuk menyelesaikan wilayah perbatasan yang masih menjadi sengketa. Pada unresolved segment di Desa Manusasi, pemerintah Indonesia dan Timor Leste berusaha membahas permasalahan yang ada dengan menggunakan pendekatan sosial dan budaya di wilayah yang bersengketa. Namun pada realisasinya, hingga tahun 2018 keduanya masih tetap mempertahankan posisinya masing-masing sehingga perundingan yang rutin dilaksanakan kedua negara belum juga berhasil menyelesaikan sengketa wilayah perbatasan yang masih tersisa.

Rentang tahun 2014 hingga 2018, terdapat pelanggaran yang dilakukan masyarakat Timor Leste. Tahun 2016, masyarakat Timor Leste masuk dan menetap di Desa Naktuka yang subur yang terletak di perbatasan Noel Besi - Citrana. Wilayah tersebut masih bersengketa dan merupakan zona netral yang tidak boleh digunakan oleh kedua masyarakat negara. Karena hal tersebut, Dewan Perwakilan Rakyat (DPR) mendesak pemerintah untuk mengirimkan nota protes kepada pemerintah Timor Leste (Bifel 2016). Tidak berhenti pada pelanggaran tersebut, di tahun 2018, secara mengejutkan pemerintah Timor Leste membuat pernyataan bahwa masyarakat Indonesia melakukan pelanggaran di Desa Manusasi. Hal tersebut dibantah oleh Komandan Korem (Danrem) 161 Wirasakti, karena menurutnya hal tersebut adalah pemutarbalikan fakta. Pasalnya saat dilakukan survey, justru di zona netral dekat pos Unidade de Patrulhamento de Fronteiras (UPF), masyarakat dengan sengaja mempersiapkan lahan untuk berladang (Nong 2018). Pelanggaran seperti ini dapat memantik konflik, namun pada kasus ini kedua negara masih bisa menahan diri untuk tidak berkonflik.

Selain pelanggaran yang dilakukan, tumpang tindih klaim garis batas mewarnai upaya penegasan batas wilayah RI-RDTL di Desa Manusasi yang dilakukan oleh pemerintah Indonesia dengan pemerintah Timor Leste. Terkait sengketa wilayah perbatasan di Desa Manusasi, pemerintah Indonesia dan Timor Leste memiliki klaim masing-masing pada garis batas sepanjang Bijael Sunan-Oben tersebut. Klaim Indonesia atas garis batas Desa Manusasi yaitu dimulai dari tugu Bijael Sunan mengikuti arah punggung gunung hingga sampai ke Oben, sedangkan klaim Timor Leste mulai dari tugu Bijael Sunan mengikuti arah lembah dan aliran sungai Miomaffa Barat hingga sampai ke Oben (Kolne 2017).

Selain itu pemerintah kedua negara juga mempunyai posisi masing-masing dalam penyelesaian sengketa wilayah perbatasan. Acuan yang digunakan selama pelaksanaan perundingan, belum menjadikan kedua pemerintah memiliki pandangan yang sama terkait penyelesaian garis batas. Posisi Indonesia melihat bahwa dalam penyelesaian 
sengketa wilayah perbatasan di Desa Manusasi, baik pemerintah Indonesia maupun pemerintah Timor Leste perlu mempertimbangkan dan menghormati hak ulayat serta hukum adat yang ada di wilayah tersebut. Berbeda dengan Indonesia, posisi Timor Leste dalam penyelesaian sengketa wilayah perbatasan di Desa Manusasi adalah dengan menggunakan hasil garis batas yang paling dekat dengan yang ada di traktat 1904, diluar dari memperhatikan masyarakat adat (Ibrahim 2017). Kondisi wilayah Desa Manusasi yang netral telah disetujui oleh kedua belah pihak, namun masyarakat Timor Leste melakukan pelanggaran dengan menggunakan dan memanfaatkan zona milik UPF sebagai lahan untuk berkebun dan bercocok tanam selama sembilan tahun. Melihat kondisi tersebut, masyarakat Indonesia menginginkan hal yang sama dengan mendesak pemerintah untuk memberikan izin bagi masyarakat setempat agar diperbolehkan untuk bercocok tanam, berkebun, dan beternak (BNPP 2018).

Berdasarkan penjabaran kronologis sengketa diatas, terlihat bahwa sengketa wilayah Indonesia-Timor Leste di Manusasi terlihat cukup pelik. Meskipun sempat terjadi beberapa bentrokan antara masyarakat di perbatasan kedua negara, namun baik Indonesia dan Timor Leste tidak pernah terlibat dalam konflik militer. Keduanya masih tetap mengupayakan penyelesaian konflik meskipun berjalan perlahan-lahan terutama dalam kurun waktu 2014-2018. Dengan kondisi ini, dapat disimpulkan bahwa dinamika sengketa di Desa Manusasi relatif stabil. Menurut tipologi sengketa wilayah dalam issue-level approach, kondisi ini muncul sebagai akibat dari kondisi kewilayahan yang salient namun kurang memiliki visibilitas di level nasional sehingga meskipun konfliknya cukup rumit untuk diselesaikan, tidak ada tekanan terhadap pemerintah untuk mempercepat penyelesaian sengketa keduanya. Untuk lebih menjelaskan bagaimana kedua faktor - kewilayahan dan visibilitas - berkontribusi pada kondisi sengketa Indonesia-Timor Leste yang masih berlangsung dengan stabil, bagian berikut akan memaparkan kaitan masing-masing faktor.

\section{Faktor Kewilayahan, Visibilitas, dan Dinamika Sengketa Wilayah di Manusasi}

Seperti yang sudah dijelaskan secara detail pada bagian sebelumnya, nilai sebuah wilayah dapat dilihat dari salient atau tidaknya wilayah tersebut. Indikator untuk menentukan sebuah negara bernilai salient adalah dengan melihat nilai tampak (tangible) dan nilai tidak tampak (intangible) yang ada. Desa Manusasi terletak di Kecamatan Miomaffa Barat, Kabupaten TTU, Provinsi NTT, dan berbatasan langsung dengan distrik Oecussi yang mana merupakan enclave yang terpisah dari bagian Timor Leste lainnya. Wilayah Desa Manusasi merupakan tanah seluas 489 bidang tanah dengan panjang 2,6 km atau 142,7 Ha. Jarak dari Desa Manusasi ke wilayah pusat Timor Leste maupun Indonesia terpaut jauh. Pada wilayah pusat Timor Leste di bagian timur jaraknya terpaut sekitar $60 \mathrm{~km}$ (Mangku D. G. 2017). Sedangkan jarak ke kabupaten TTU yaitu sekitar $30 \mathrm{~km}$. Sebagian besar mata pencaharian masyarakat di sekitar wilayah Desa Manusasi adalah bertani, dan sebagian kecilnya beternak, namun dengan pekerjaan tersebut hanya cukup untuk kebutuhan harian. Kondisi air bersih di Desa Manusasi sangat terbatas, sehingga menjadi masalah utama di wilayah tersebut, terlebih saat musim kemarau tiba. Akses listrik serta sinyal di Desa Manusasi tergolong cukup baik, namun untuk akses jalanannya masih terdapat jalan yang berlubang (BNPP 2018). 
Desa Manusasi meskipun relatif lebih maju dibanding perbatasan lain, tetapi tidak memiliki nilai yang tampak, baik dalam sumber daya alam maupun sumber daya manusia karena merupakan wilayah kosong yang tidak dihuni serta tidak digunakan untuk beraktivitas oleh masyarakat. Dengan kondisi Desa Manusasi yang masih bersengketa, baik pemerintah Indonesia maupun pemerintah Timor Leste menyepakati untuk tidak memperbolehkan warganya menggunakan wilayah tersebut, karena berpotensi menimbulkan konflik antara kedua pihak (Sianipar 2017). Melihat hal tersebut, indikator pertama pada nilai tampak (tangible) tidak terdapat di Desa Manusasi, karena harus terdapat sumber daya alam di wilayah yang bersengketa. Dengan kondisi Desa Manusasi yang tidak memiliki sumber daya alam potensial, kondisi tersebut pun juga tidak mengganggu dan tidak mempengaruhi stabilitas serta power suatu negara karena tidak ada perebutan sumber daya alam antar kedua negara. Kondisi yang ada justru terjalinnya hubungan baik antara kedua negara. Dengan posisi yang bertetangga, secara langsung maupun tidak, kedua negara akan membutuhkan satu sama lain dan hal tersebut dapat menjaga stabilitas kedua negara (Wuryandari 2009).

Pada wilayah Desa Manusasi, masyarakat adat dari kedua negara tidak ada yang tinggal di wilayah tersebut. Baik masyarakat adat Indonesia maupun masyarakat adat Timor Leste, keduanya menetap di sekitar wilayah yang bersengketa. Bukan tanpa alasan kondisi Desa Manusasi steril dan tidak dihuni penduduk di sekitar wilayah tersebut. Hal ini dilakukan pemerintah kedua negara untuk menghindari potensi terjadinya konflik antar warga di wilayah tersebut. Saat ini Desa Manusasi dipergunakan oleh pihak keamanan kedua negara untuk menjaga stabilitas dan keamanan di wilayah tersebut dengan membaginya menjadi tiga zona. Zona 1 merupakan zona patroli Tentara Nasional Indonesia (TNI), zona 2 sebagai kawasan netral dari keduanya dan zona 3 sebagai zona patroli Unidade de Patrulhamento de Fronteiras (UPF) (BNPP, 2018). Melihat hal-hal tersebut, Desa Manusasi tidak memenuhi indikator dari nilai tampak (tangible) sengketa wilayah.

Meskipun tidak memiliki nilai tampak, Desa Manusasi memiliki nilai tidak tampak (intangible) yang mana menurut teori hal tersebut menjadikan sengketa wilayah berjalan lebih alot dibanding dengan yang memiliki nilai tampak. Nilai tidak tampak sendiri mencakup hal yang tidak terlihat wujudnya, memiliki hal simbolis serta adanya keterkaitan emosional antar masyarakat. Dengan kata lain sengketa ini berkaitan dengan wilayah yang memiliki simbol yang berkaitan dengan identitas kolektif masyarakat setempat seperti bangunan dengan nilai kesejarahan atau keagamaan. Sengketa wilayah perbatasan yang terjadi di Desa Manusasi merupakan sengketa tanah adat. Hukum adat terkait tanah merupakan hukum adat yang paling kuat. Bagi masyarakat adat, tanah memiliki posisi yang sangat penting baik secara sifat maupun fakta yang ada. Secara sifat, dengan kondisi seperti apa pun, tanah adat merupakan satu-satunya kekayaan dalam bentuk benda. Sedangkan secara fakta tanah adat merupakan tempat tinggal roh leluhurnya (Kalembang 2018). Kedua masyarakat adat Indonesia maupun Timor Leste yang berada di sekitar Desa Manusasi, memiliki keinginan untuk bisa mengklaim wilayah tersebut menjadi bagian dari wilayah negaranya. Masyarakat sekitar yang berada di Indonesia menginginkan pengukuran garis batas menggunakan pilar pertama yang ditanam oleh pemerintah Indonesia pada tahun 1966. Sedangkan masyarakat sekitar yang berada di Timor Leste menginginkan, pengukuran menggunakan pilar kedua yang sudah ada sejak tahun 1915 dan ditanam karena menjadi hasil kesepakatan antara Belanda dan Portugis (Sianipar 2017). Desa 
Manusasi menjadi simbol sejarah adat di Pulau Timor, sehingga baik masyarakat sekitar yang ada di Indonesia maupun Timor Leste menginginkan tanah ulayat tersebut bisa secara utuh masuk ke wilayah mereka. Hak ulayat sendiri merupakan hak masyarakat adat terkait wilayah tanah maupun perairan serta isinya untuk digunakan dan diatur segala yang berkaitan dengan tanah dan perairan tersebut termasuk lingkungannya dan dilaksanakan di bawah pimpinan kepala adat (Kalembang 2018).

Timor Leste merupakan negara yang sebelumnya bagian dari Indonesia. Pernah berada dalam satu rumpun wilayah serta dalam satu kesatuan sejarah adat, tentu tidak dengan mudah menghapus maupun membatasi hubungan yang sudah ada antara masyarakat di sekitar Desa Manusasi, baik yang berada di wilayah Indonesia maupun Timor Leste. Masyarakat adat Indonesia dan Timor Leste yang berada di sekitar Desa Manusasi memiliki hubungan sosial dan hubungan kekeluargaan yang cukup erat. Hal tersebut dikarenakan adanya pernikahan antara masyarakat adat dari kedua negara. Selain itu keduanya memiliki kesamaan suku, yaitu suku Atoni Meto dan menurut sejarah, keduanya berasal dari nenek moyang yang bersaudara, sehingga masih berasal dari satu garis keturunan yang sama (Kolne 2017). Dinamika ini pun turut mempengaruhi kompleksnya penarikan batas diantara kedua kelompok masyakarat tersebut.

Melihat hasil analisis di atas, sengketa wilayah di Desa Manusasi bernilai penting (salient) karena memenuhi indikator dari nilai tidak tampak (intangible) yang ada. Sengketa wilayah di Desa Manusasi disebabkan tanah ulayat, karena wilayah tersebut menjadi hal simbolis yang kental akan sejarah leluhur bagi masyarakat adat. Keberadaan masyarakat kedua negara yang berada di sekitar wilayah Desa Manusasi memiliki keterkaitan karena adanya pernikahan lintas negara serta masih merupakan satu keturunan dari nenek moyang yang bersaudara. Sengketa wilayah yang bernilai salient karena permasalahan simbolis yang ada di wilayah tersebut, akan cenderung memiliki tensi yang tinggi dan tidak mudah untuk diselesaikan. Hal tersebut dikarenakan hal simbolis yang sudah ada sejak dahulu di wilayah tersebut bersifat tidak bisa dibagi (indivisible). Dengan demikian, lamanya negosiasi sengketa di Manusasi merupakan konsekuensi dari kondisi kewilayahan ini. Meskipun demikian, wilayah yang salient tidak serta membuat konfliknya bereskalasi. Berdasarkan tipologi issuelevel approach, masih ada faktor visibilitas yang turut menentukan arah dinamika sengketa. Sengketa menjadi tidak stabil jika didukung oleh visibilitas sengketa yang tinggi diantara masyarakat, sementara dapat tetap relatif stabil jika visibilitas diantara masyarakat rendah sehingga kurang ada tekanan terhadap pemerintah untuk segera menyelesaikan isu ini.

\section{Faktor Visibilitas di Level Nasional}

Dengan melihat kondisi sengketa yang relatif stabil, secara teori, berarti visibilitas di level nasional rendah. Berdasarkan media tracking antara tahun 2014-2018, baik media massa di level nasional teratas Indonesia maupun Timor Leste pun tidak terlihat menjadikan sengketa wilayah perbatasan di Desa Manusasi sebagai pokok berita. Pemberitaan terkait masalah tersebut hanya diberitakan beberapa kali di media massa dan pemberitaannya hanya membahas sengketa secara umum atau hubungan kerjasama antara keduanya di level pemerintahan.

Pada tahun 2014, misalnya, tidak ada bahasan sama sekali tentang masalah perbatasan di Desa Manusasi maupun masalah perbatasan RI-RDTL lainnya. Tahun 2015 di media 
Timor Leste, terdapat artikel berita yang berjudul "TL-Indonesia Konkorda Diskute Area Disputa Iha Oecusse" "“TL-Indonesia sepakat mendiskusikan wilayah sengketa di Oecussi") oleh Suara Timor Lorosae. Berita tersebut menjelaskan kesepakatan kedua negara untuk menyelesaikan masalah perbatasan di Oecussi. Hal tersebut dilakukan karena sengketa wilayah perbatasan yang ada belum terselesaikan oleh masyarakat setempat (Sanches 2015). Selain itu, media dari Indonesia yang berjudul "Jokowi: Ada dua Titik Perbatasan yang Belum Selesai” oleh detik.com juga menjelaskan secara umum, bahwa perbatasan yang masih tersisa berlokasi di Desa Manusasi (Bijael Sunan-Oben) dan Desa Naktuka (Noel Besi-Citrana). Kedua pemerintah pun sepakat untuk segera menyelesaikannya (Jordan 2015).

Dua tahun kemudian yaitu pada 2016, terdapat pemberitaan dari media di Indonesia yang berjudul "Belum Ada Titik Temu antara Indonesia dan Timor Leste soal Sengketa Dua Titik Perbatasan" oleh kompas.com. Pemberitaan ini lebih menyampaikan hasil rapat terbatas antar kementerian yang mendiskusikan rekomendasi bagi dua unresolved segment Indonesia-Timor Leste (Erdianto, K. 2016). Dari pihak Timor Leste sendiri, tidak ada pemberitaan yang membahas permasalahan sengketa antara kedua negara maupun proses penyelesaian yang sedang diupayakan.

Pada tahun 2017 kembali media dari Timor Leste mengeluarkan berita, "TL-RI Sedauk Finaliza Fronteira Terrestre" ("TL-Indonesia belum menyelesaikan batas wilayah darat") oleh Suara Timor Lorosae, yang menyampaikan bahwa Presiden Joko Widodo dan Presiden Francisco Guterres ingin segera menyelesaikan sengketa wilayah perbatasan yang masih tersisa dan belum mencapai kesepakatan (Manuel 2017). Selaras dengan pemberitaan yang ada di Timor Leste, media dari pihak Indonesia yang berjudul "Atasi Sengketa Wilayah, Indonesia-Timor Leste Bentuk Tim Khusus" oleh Kompas, memberitakan pertemuan antara Wiranto selaku Menteri Koordinator Bidang Politik, Hukum dan Keamanan, Retno Marsudi selaku Menteri Luar Negeri Indonesia dan Xanana Gusmao selaku Menteri Perencanaan dan Investasi Strategis Republik Demokratik Timor Leste. Ketiganya membahas permasalahan unresolved segment yang masih tersisa, dan menyepakati pembentukan Senior Officer Committee (SOC) sebagai upaya lanjutan penyelesaian sengketa wilayah perbatasan (Erdianto, K. 2017). Pemberitaan lain yang berjudul "Mei 2017, Masalah perbatasan RI-Timor Leste ditargetkan selesai" oleh Liputan 6, seakan menjadi kelanjutan berita sebelumnya. Berita tersebut menjelaskan bahwa pada pertemuan pertama SOC, kedua pemerintah sepakat untuk mengupayakan solusi yang tepat untuk segera menyelesaikan masalah perbatasan yang masih belum terselesaikan. Keduanya juga menargetkan, permasalahan unresolved segment akan selesai pada bulan Mei (Tuwo, A. G. 2017).

Tahun 2018 pun memiliki tren yang sama. Media Timor Leste menerbitkan berita terkait perbatasan wilayahnya dengan Indonesia di tahun 2018 dalam artikel berita berjudul "TL-Indonesia Hahu Komunika Malu Ba Fronteira Maritima" ("Timor Leste dan Indonesia memulai membicarakan mengenai batas laut") oleh Dilli Weekly. Artikel tersebut menjelaskan bahwa pemerintah Timor Leste dan Indonesia mulai membahas permasalahan batas laut yang belum ditegaskan. Pihak Timor Leste menyampaikan bahwa batas laut negaranya dengan Australia sudah berhasil terselesaikan dan berharap perbatasan laut dengan Indonesia pun bisa segera selesai dan ditegaskan (Nuno E. 2018). Tahun yang sama, terdapat pemberitaan dari media di Indonesia yaitu "Indonesia-Timor Leste Sepakat Tingkatkan Perdagangan dan Investasi" oleh Liputan 6. Presiden Joko Widodo menyampaikan hasil pertemuannya dengan Presiden Timor Leste, Francisco Guterres terkait kesepakatan untuk meningkatkan kerjasama dalam 
bidang perdagangan dan investasi (Liputan6 2018). Berita tersebut tidak membahas masalah perbatasan yang masih berlangsung antara Indonesia dan Timor Leste, namun hanya kesepakatan kedua pemerintah terkait peningkatan kerjasama kedua negara.

Dengan paparan tersebut, terlihat bahwa sengketa wilayah perbatasan di Desa Manusasi memang tidak terlihat di masyarakat nasional sesuai dengan tipologi sengketa relatif stabil yang merupakan vektor dari kewilayahan yang salient namun secara visibilitas nasional kurang. Beberapa hal dapat membantu menjelaskan kurangnya visibilitas ini pada rentang waktu 2014-2018. Pertama, dari level pemerintah, baik pemerintah Indonesia maupun Timor Leste tidak ingin masalah yang ada diangkat hingga tingkat nasional. Sengketa wilayah perbatasan yang masih belum terselesaikan antara Indonesia-Timor Leste menjadi hal yang akan diselesaikan bersama-sama oleh kedua belah pihak dengan jalur damai. Pemerintah kedua negara berkomitmen untuk menjaga hubungan keduanya. Hubungan yang terjalin antara Indonesia dan Timor Leste berlangsung baik sehingga masalah sengketa perbatasan tidak menjadi hal yang perlu di angkat ke level nasional oleh pemerintah kedua negara. Permasalahan yang ada hanya tetap didiskusikan namun lebih banyak dibahas oleh instansi pemerintahan yang memang terlibat langsung dalam upaya penyelesaian sengketa wilayah perbatasan antara RI-RDTL.

Kedua, masyarakatadat Indonesia dan Timor Lesteyang berada di sekitar Desa Manusasi sendiri ingin agar permasalahan batas wilayah diselesaikan melalui pertemuan adat. Pada pernyataannya kepada tim rri.co.id, Raja Malaka yang merupakan salah satu tokoh adat dari pihak Indonesia menyampaikan bahwa, penyelesaian sengketa wilayah di Desa Manusasi tidak perlu melalui jalur politik. Tokoh adat mengharapkan pemerintah untuk memfasilitasi pertemuan antara raja yang berada di Indonesia dengan Timor Leste. Ia mengatakan bahwa Timor Leste merupakan saudara, yang mana dahulu berada dalam satu rumpun wilayah, sehingga penyelesaian dalam tingkat masyarakat adat menjadi hal yang diperlukan (Tally 2016). Dalam hal ini, permasalahan sengketa wilayah perbatasan di Desa Manusasi tidak menjadi konsumsi publik karena masyarakat adat yang berada di sekitar wilayah tersebut lebih condong untuk menyelesaikannya secara kekeluargaan bukan atas dasar kepentingan politik kedua pemerintah negara.

Ketiga, terdapat juga faktor karakter kedua negara yang sama-sama merupakan negara berkembang. Salah satu kecenderungan negara berkembang adalah fokusnya pada berbagai permasalahan domestik yang terjadi di negara tersebut (inward-looking). Hal ini dapat terlihat dari pemberitaan di media yang menjadi headline pada rentang tahun 2014-2018. Di tahun 2014, Indonesia terfokus pada pemilihan umum presiden. Di tahun 2015, terjadi kebakaran hutan yang cukup banyak hingga memberikan dampak asap ke negara tetangga seperti Malaysia, sehingga pemerintah berfokus untuk menanganinya. Pada tahun 2017, Indonesia kembali mengadakan pemilihan umum untuk kepala daerah. Sedangkan di tahun 2018, Indonesia menjadi tuan rumah pesta olahraga terbesar di Asia Tenggara, yaitu Asian Games dan Asian Para Games. Sebagai tuan rumah, Indonesia memperhatikan setiap detail persiapan termasuk menjaga netralitas pemberitaan media agar tidak menimbulkan opini tertentu dari masyarakat Internasional yang mana turut berpartisipasi dalam perhelatan akbar tersebut. Selain itu, di tahun yang sama, Indonesia juga mengalami beberapa musibah bencana alam di berbagai daerah, sehingga hal tersebut memerlukan penanganan lebih dahulu. 
Dengan melihat kondisi tersebut, dapat terlihat bahwa masalah domestik serta tantangan yang dihadapi masih cukup banyak. Indonesia sebagai salah satu negara berkembang juga memiliki banyak fokus yang perlu diselesaikan. Pada masalah sengketa wilayah perbatasan sendiri, Indonesia masih memiliki banyak pekerjaan rumah yang harus diselesaikan. Tidak hanya bersinggungan secara langsung dengan Timor Leste, Indonesia juga berbatasan dengan Malaysia dan Papua Nugini. Sengketa wilayah perbatasan dengan dua negara lain tersebut juga menjadi hal yang sedang diupayakan penyelesaiannya oleh pemerintah, sehingga sengketa wilayah perbatasan antara Indonesia dengan Timor Leste pada unresolved segment di Desa Manusasi tidak secara fokus diselesaikan oleh pemerintah.

Keempat, karakter perbatasan yang terletak di posisi teluar negara suatu negara juga berpengaruh pada visibilitas sengketa di level nasional. Desa Manusasi, terletak di Provinsi NTT, Indonesia dan bersinggungan langsung dengan distrik Oecussi, Timor Leste. Tidak hanya jauh dari pemerintah Indonesia, Desa Manusasi terpaut jarak yang jauh juga dari pemerintah Timor Leste karena ibu kotanya terletak di Dili, yang mana letak wilayahnya tidak satu wilayah dengan Oecussi dan berada di bagian lain yang perlu melewati wilayah Indonesia. Lokasi Desa Manusasi terletak jauh dari pusat pemerintahan yang berada di Jakarta dan berbeda pulau. Dengan kondisi tersebut, permasalahan sengketa wilayah antara RI-RDTL di Desa Manusasi tidak mudah untuk sampai masyarakat yang sebagian besar berada di Pulau Jawa, sehingga kurang menjadi bahasan diantara masyarakat mayoritas.

Dengan kondisi wilayah di Desa Manusasi yang bernilai salient, kedua negara tidak menitik beratkan hubungan bilateralnya pada penyelesaian wilayah sengketa dalam waktu singkat. Beberapa artikel berita yang dibuat oleh media nasional membahas permasalahan sengketa wilayah perbatasan Desa Manusasi secara umum. Dalam pemberitaan tersebut kondisi yang diperlihatkan pada publik merupakan proses perundingan sengketa wilayah yang berjalan dengan kondisi baik tanpa adanya kegentingan untuk segera menyelesaikan masalah ini. Melihat hal tersebut, permasalahan sengketa wilayah di Desa Manusasi tidak terlihat di masyarakat nasional. Sebagai konsekuensinya, permasalahan sengketa wilayah tersebut tidak berujung pada demonstrasi nasional oleh masyarakat yang mana dapat mendorong pemerintah untuk melakukan sebuah tindakan maupun kebijakan segera terkait permasalahan yang berlangsung. Pemerintah kedua negara lebih memiliki fleksibilitas dalam menyelesaikan sengketa sesuai dengan dinamika negosiasi bilateral kedua negara.

\section{Simpulan}

Tulisan ini bertujuan untuk melihat faktor penghambat penyelesaian sengketa wilayah Indonesia dan Timor Leste di Desa Manusasi hingga 2018 dengan menggunakan issue-level approach. Berdasarkan uraian diatas, terlihat bahwa faktor penghambat penyelesaian sengketa ini terletak pada permasalahan di level masyarakat karena nilai simbolis dari Desa Manusasi itu sendiri dan ditambah dengan kurangnya visibilitas sengketa ini di level nasional yang membuat kurang adanya tekanan bagi pemerintah untuk segera menyelesaikan sengketa ini. Dengan demikian, tipologi issue-level approach yang melihat bahwa dinamika sengketa yang masih terus berjalan namun relatif stabil dikarenakan kombinasi faktor kewilayahan yang miliki nilai tertentu 
namun memiliki visibilitas nasional yang kurang menemukan bukti pendukungnya dalam kasus ini. Secara lebih luas, temuan tulisan ini memperlihatkan pentingnya melihat faktor politis dalam mengkaji sengketa wilayah selain tentunya legal dan teknis yang telah banyak dikembangkan. Faktor kewilayahan dan visibilitas terutama merupakan dua faktor penting yang berpengaruh dalam dinamika sengketa. Pada kasus Manusasi terlihat bahwa kondisi tetap stabil meskipun wilayah yang disengketakan salient salah satunya dapat dilihat sebagai keberhasilan pemerintah mengelola konflik tersebut. Dalam banyak kasus lain, sengketa wilayah yang salient sering berujung pada konflik militer terbuka karena visibilitas isu ini di level nasional yang membuat tekanan terhadap pemerintah dari berbagai kelompok kepentingan tinggi.

\section{Referensi}

\section{Buku dan Bab dalam Buku}

Creswell, J. W, 2007. Qualitative Inquiry \& Research Design: Choosing Among Five Approaches. Thousand Oaks, London, New Delhi: Saga Publications.

Ibrahim, M., 2017. Pengelolaan Batas Negara Wilayah Darat. Jakarta: Badan Nasional Pengelola Perbatasan.

Wuryandari, G., 2009. Keamanan Di Perbatasan Indonesia-Timor Leste: Sumber Ancaman dan Kebijakan Pengelolaannya. Yogyakarta: Jakarta: Pustaka Pelajar.P2P-LIPI

\section{Jurnal dan Jurnal Daring}

Anggita, M., 2014. “Kesepakatan Batas Darat RI-Timor-Leste: Sebuah Kajian Diplomasi Perbatasan RI”, Jurnal Penelitian Politik, 11(1), 21-38.

Bangun, B. H., 2017. “Konsepsi dan Pengelolaan Wilayah Perbatasan Negara: Perspektif Hukum Internasional”, Tanjungpura Law Journal, 1(1), 52-63.

Darmaputra, R., 2009. "Manajemen Perbatasan dan Reformasi Sektor Keamanan". Jakarta: IDSPS Press.

Dzurek, Daniel J., 2005. "What Makes Territory Important: Tangible and Intangible Dimensions", Geo Journal, 64(4), 263-274.

Gumilar, N., 2017. "Dukungan Kampanye Militer Terhadap Diplomasi Indonesia di Perbatasan Darat Indonesia - Timor Leste”, Jurnal pertahanan \& Bela Negara, $7(2), 217-226$.

Handoyo, S., 2011. "Geospatial Aspect of the Land Border between Indonesia and Timor-Leste", Globe, 13(2), 175-183.

Hensel, Paul R and Sara Mclaughlin., 2005. "Issue Indivisibility and Territorial Claims". Geo Journal, 64(4), 275-285.

Kalembang, Elpius., 2018. “Tanah Ulayat Sebagai Simbol Eksistensi Adat-Istidat: Studi Kasus tentang Konflik Tanah Ulayat di Perbatasan Republik Indonesia (RI) dan Republik Demokratik Timor Leste (RDTL) Segmen Bijael Sunan/ 
Oelna”, Sabda, 13(1), 44-58.

Kolne, Y., 2014. "Implementasi Perjanjian Perbatasan RI-RDTL dalam Upaya Penyelesaian Masalah Perbatasan: Studi Kasus di Kabupaten TTU-RI dengan Distrik Oecusse-RDT”, Politika, 5(1), 1-14.

Kolne, Y., 2017. "Penyelesaian Konflik Perbatasan Unresolved dan Unsurveyed Segmen Bijael Sunan-Oben Melalui Pendekatan Budaya”, Politika, 8(2), 42-51.

Mangku, D. G., 2017. "Peran Border Liasion Committee (BLC) Dalam Pengelolaan Perbatasan Antara Indonesia dan Timor Leste”, Perspektif, 22(2), 80-95.

Pertiwi, S.B., 2014. "The Rise of Territorial Disputes \& the stability of Southeast Asia", American University, 1-153.

Puspitasari, Yeni, 2013. "Upaya Indonesia Dalam Menangani Masalah Keamanan Perbatasan Dengan Timor Leste Pada Periode 2002-2012”, Skripsi Prodi Hubungan Internasional UIN Jakarta, 1-52.

Qinvi, R. F.; Sutisna, S.; Widodo, P., 2018. "Diplomasi Pertahanan Dalam Penyelesaian Unresolved Segment di Perbatasan Darat Indonesia - Republik Demokratik Timor Leste (RDTL) (Studi Kasus Unresolved Segment Dilumil - Memo)", Jurnal Prodi Diplomasi Pertahanan, 4(1), 57-82.

Raharjo, Sandy Nur Ikfal, 2014. "Analisis dan Upaya Penyelesaian Konflik Antara Warga Perbatasan Timor Tengah Utara, Indonesia dengan Warga Distrik Oecussi, Timor Leste pada 2012-2013”, Jurnal Pertahanan, 4(1), 155-174.

Raharjo, Sandy Nur Ikfal, 2016. "Research Summary Managing Conflict Through: Cross-Border Cooperation: A Study at Indonesia-Timor Leste Border”, Journal of Indonesian Social Sciencies and Humanities, 6(1), 71-79.

Rahmat, P. S., 2009. "Penelitian Kualitatif". Equilibrium, 5(9), 1-8.

Sianipar, I. M., 2017. "Upaya Penyelesaian Sengketa Wilayah Perbatasan Darat Indonesia - Timor Leste”, Sociae Polites, 18(1), 1-13.

Somantri, G. R., 2005. "Memahami Metode Kualitatif", Makara, Sosial Humaniora, $9(2), 57-65$.

Quefi, Lourenco Tla'an; Tadeus, Dhey Wego; Yohanes, Saryono., 2019. "Penanganan Permasalahan Perbatasan Negara Indonesia dan Distrik Oecusse-Timor Leste (Studi Kasus di Naktuka Desa Bene Ufe Nitibe Regiao Oecusse)”, Jurnal Proyuris, Vol.1, No. 1, 28-42.

\section{Artikel Daring}

Aritonang, M., 2015. "Discourse: Indonesia,Timor Leste have developed a mature relationship: PM" [online] dalam https://www.thejakartapost.com/ news/2015/08/31/discourse-indonesiatimor-leste-have-developed-a-maturerelationship-pm.html [Diakses pada 9 Juli 2019].

Bere, S. M., 2012. "Warga Perbatasan RI dan Warga Timor Leste Terlibat Bentrok" [online] dalam https://regional.kompas.com/read/2012/08/01/10040034/warga. perbatasan.ri.dan.warga.timor.leste.terlibat.bentrok [Diakses pada 11 Juli 2019]. 
Bifel, H., 2016. "Warga Timor Leste Diminta Tinggalkan Zona Bebas" [online] dalam https://www.antaranews.com/berita/540927/warga-timor-leste-diminta-tinggalkanzona-bebas [Diakses pada 11 Juli 2019].

Erdianto, K., 2016. "Belum Ada Titik Temu antara Indonesia dan Timor Leste soal Sengketa Dua Titik Perbatasan" [online] dalam https://nasional.kompas.com/ read/2016/11/11/21331991/belum.ada.titik.temu.antara.indonesia.dan.timor.leste. soal.sengketa.dua.titik.perbatasan [Diakses pada 11 Juli 2019].

Erdianto, K., 2017. "Atasi Sengketa Wilayah, Indonesia-Timor Leste Bentuk Tim Khusus" [online] dalam https://nasional.kompas.com/read/2017/02/13/17420051/ atasi.sengketa.wilayah.indonesia-timor.leste.bentuk.tim.khusus.?page $=2$ [Diakses pada 29 Agustus 2019].

Firman, Tony., 2017. "Timor Leste Pada Masa Kolonial” [online] dalam https://tirto. id/timor-leste-pada-masa-kolonial-co55 [Diakses pada 8 Juli 2019].

Firman, Tony., 2016. "Mengingat Referendum, Jalan Panjang Kemerdekaan Timor Leste" [online] dalam https://tirto.id/mengingat-referendum-jalan-panjang-kemerdekaan-timor-leste-bFyB [Diakses pada 8 Juli 2019].

Jordan, R., 2015. "Jokowi: Ada Dua Titik Perbatasan Darat RI-Timor Leste yang Belum Selesai" [online] dalam https://news.detik.com/berita/d-3001724/ jokowi-ada-dua-titik-perbatasan-darat-ri-timor-leste-yang-belum-selesai? $\mathrm{ga}=2.253859272 .1133897611 .1567045761-2114450714.1560319852$ [Diakses pada 29 Agustus 2019].

Kemlu RI, 2018. “Kedutaan Besar Republik Indonesia di Dili; Media TL” [online] dalam https://kemlu.go.id/dili/id/pages/media tl/1738/etc-menu [Diakses pada 29 Agustus 2019].

Kuwado, F.J., 2018. “Jokowi: Indonesia BerkomitmenJadi Mitra Terpercaya BagiTimor Leste" [online] dalam https://nasional.kompas.com/read/2018/06/28/12153061/ jokowi-indonesia-berkomitmen-jadi-mitra-terpercaya-bagi-timor-leste [Diakses pada 9 Juli 2019].

Liputan 6., 2009. "Dinamika Politik Timor Leste di Bawah Xanana" [online] dalam https://www.liputan6.com/news/read/242464/dinamika-politik-timor-leste-dibawah xanana?related=dable\&utm expid=.9Z4i5ypGQeGiS7w9arwTvQ.1\&utm

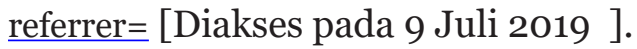

Liputan6,2018. "Indonesia-TimorLesteSepakatTingkatkanPerdagangandanInvestasi" [online] dalam https://www.liputan6.com/global/read/3573003/indonesiatimor-leste-sepakat-tingkatkan-perdagangan-dan-investasi?related=dable\&utm expid=.9Z4i5ypGQeGiS7w9arwTvQ.1\&utm referrer=https\%3A\%2F\%2Fwww.google. com\%2F [Diakses pada 11 juli 2019].

Manuel, J., 2017. “TL-RI Sedauk Finaliza Fronteira Terrestre” [online] dalam https:// suara-timor-lorosae.com/tl-ri-sedauk-finaliza-fronteira-terrestre/ [Diakses pada 11 Juli 2019].

Morgan, R, 2018. "Detik.com, Kompas.com \& Liputan6 are Indonesia's leading news websites" [online] dalam http://www.roymorgan.com/findings/7622-top-10indonesian-news-websites-march-2018-201806172227 [Diakses pada 29 Agustus 2019].

Nong, R., 2018. "Danrem 161 Wirasakti Membantah Warga Perbatasan Caplok Wilayah RDTL” [online] dalam https://kupang.tribunnews.com/2018/o9/og/danrem-161- 
wirasakti-membantah-warga-perbatasan-caplok-wilayah-rdtl?page=all $\quad$ [Diakses pada 11 Juli 2019].

Nuno, E., 2018. "TL-Indonesia Hahu Komunika Malu Ba Fronteira Maritima” [online] dalam http://www.thediliweekly.com/tl/notisias/kapital/16112-tl-indonesia-hahukomunika-malu-ba-fronteira-maritima [Diakses pada 31 Agustus 2019].

Pangayunan, A. D., 2019. "Oecusse, Tempat Mendarat Bangsa Portugis di Pulau Timor" [online] dalam https://travel.kompas.com/read/2019/04/06/091500127/ oecusse-tempat-mendarat-bangsa-portugis-di-pulau-timor?page=all [Diakses pada 8 Juli 2019].

Pratama, A. N., 2018. "Hari Ini dalam Sejarah: Referendum Timor Timur" [online] dalam https://internasional.kompas.com/read/2018/08/30/20254771/hari-inidalam-sejarah-referendum-timor-timur?page=2 [Diakses pada 11 Juli 2019].

Sanches, T., 2015. "TL-Indonesia Konkorda Diskute Area Disputa Iha Oecusse' [online] dalam https://suara-timor-lorosae.com/tl-indonesia-konkorda-diskutearea-disputa-iha-oecusse/ [Diakses pada 11 Juli 2019].

Seo, Y., 2012. "Tiga Segmen Batas RI-Timor Leste Masih Sengketa" [online] dalam https://nasional.tempo.co/read/423716/tiga-segmen-batas-ri-timor-leste-masihsengketa [Diakses pada 8 Juli 2019].

Seo, Y., 2013. "Indonesia-Timor Leste Saling Klaim Batas Negara" [online] dalam https://nasional.tempo.co/read/523405/indonesia-timor-leste-saling-klaim-batasnegara/full\&view $=$ ok [Diakses pada 11 Juli 2019].

Seo, Y., 2013. "Timor Leste Disebut Langgar Kesepakatan Perbatasan” [online] dalam https://nasional.tempo.co/read/522412/timor-leste-disebut-langgar-kesepakatan-perbatasan/full\&view=ok [Diakses pada 11 Juli 2019 ].

Tally, Vanny., 2016. "Raja Malaka Tidak Sepakat Penyelesaian Batas Wilayah Manusasi RI-RDTL Menggunakan Pendekatan Politik" [online] dalam http://rri.co.id/ post/berita/305954/daerah/raja malaka tidak sepakat penyelesaian batas wilayah manusasi rirdtl menggunakan pendekatan politik.html [Diakses pada 8 Juli 2019].

Tuwo, A. G., 2017. "Mei 2017 Masalah perbatasan RI-Timor Leste ditargetkan selesai" [online] dalam https://www.liputan6.com/global/read/2884636/mei-2017masalah-perbatasan-ri-timor-leste-ditargetkan-selesai?source=search [Diakses pada 2 September 2019].

\section{Lain-Lain}

Asdep Batas Negara Wilayah Darat, 2018. "Perkembangan Pengelolaan Batas Negara Wilayah Darat RI-RDTL”. Jakarta: Deputi Bidang Pengelolaan Batas Wilayah Negara, Badan Nasional Pengelola Perbatasan (BNPP).

Asdep Pengelolaan Batas Negara Wilayah Darat, 2016. "Perkembangan Penyelesaian Penegasan Batas Wilayah Negara RI-RDTL". (pp. 1-19). Jakarta: Badan Nasional Pengelola Perbatasan.

Asdep Batas Negara Wilayah Darat, 2018. "Rekomendasi kebijakan penyelesaian dan pengelolaan unresolved dan unsurveyed segments RI-RDTL”. Jakarta Asdep Batas Negara Wilayah Darat, Badan Nasional Pengelola Perbatasan (BNPP). 
Badan Infomasi Geospasial, 2016. "Status Unresolved dan Unsurveyed Segmen RITIMOR LESTE”. PowerPoint presentation at Kemenkopolhukam, Jakarta.

Bappenas, 2012. "Peran Masyarakat Adat Dalam Perumusan Kebijakan Publik". Jakarta: Direktorat Politik dan Komunikasi Bappenas. 